\title{
Cerita Si Kuncung: Membaca Relasi Kuasa dalam Majalah Anak-anak Indonesia
}

\author{
Atika S. Hadi \\ Magister Ilmu Sejarah, Fakultas Ilmu Budaya, Universitas Indonesia \\ Alamat korespondensi: atika.ash@gmail.com
}

Diterima / Received: 25 November 2018

Disetujui / Accepted: 2 Desember 2018

\section{Abstract}

Si Kuncung is the first kid's magazine that officially accepted as a national kids magazine by the Indonesian government in the era of President Soeharto. Aside from being a media for education and culture, the government also helped $S i$ Kuncung's publications, especially in marketing and financing. The relationship between the publishers and the government expanded the deployment of $S i$ Kuncung and strengthened its position in the national children's reading materials. However, on the other hand, Si Kuncung who dissolved in the leadership of power also faded along with the collapse of the New Order era.

Keywords: Si Kuncung; Kid's Magazine; Power Relation.

Abstrak

Si Kuncung merupakan majalah anak-anak pertama yang didaulat secara resmi sebagai majalah anak nasional oleh pemerintah Indonesia pada era Presiden Soeharto. Selain sebagai media pendidikan dan kebudayaan, pemerintah juga turut membantu penerbitan Si Kuncung dari segi pemasaran dan pembiayaan. Relasi yang terjalin antara pihak penerbit dengan pemerintah memperluas penyebaran Si Kuncung dan memperkuat posisi Si Kuncung dalam jajaran bacaan anak-anak nasional. Namun di sisi lain, Si Kuncung yang terlarut dalam kepemimpinan kekuasaan turut meredup seiring runtuhnya Orde Baru.

Kata Kunci:. Si Kuncung; Majalah Anak-Anak; Relasi Penguasa.

\section{Pendahuluan}

Anak-anak menanggung beban tentang apa yang akan terjadi di masa depan. Pandangan tentang anak-anak sebagai makhluk kecil yang belum sempurna membuat masa kanak-kanak dipenuhi dengan mimpi dan idealisme orang dewasa. Secara berantai, masa kanak-kanak akan memengaruhi keputusan-keputusan mereka di masa yang akan datang, dan kembali membentuk idealisme masa kanakkanak mereka pada generasi selanjutnya. Kondisi demikian menempatkan anakanak sebagai sebuah kelompok masyarakat yang paradoksal. Mereka mengandung impian dan juga kekhawatiran, dicintai sekaligus ditakuti (Sartre, 2009, p. 19).

Namun sejarah sering kali melupakan masa kanak-kanak dalam catatancatatannya. Cerita tentang bagaimana mereka dibesarkan, apa yang mereka lakukan, mereka gunakan dan kenakan jarang muncul sebagai tema-tema penulisan sejarah yang komprehensif. Hal ini membuat penulisan sejarah tentang anak-anak ibarat padang rumput yang luas dan hijau, bebas untuk ditanami atau dibangun sekaligus membingungkan untuk memulai dari mana.

Kehadiran Si Kuncung dalam penelitian ini dapat dilihat sebagai sebuah celah untuk mengintip dunia anak-anak di masa lalu. Melalui perjalanan penerbitannya serta relasinya dengan pemilik kekuasaan, dapat dipahami dunia baca anak-anak dibentuk dan dikonstruksi dalam periode yang cukup panjang, yang disadari atau 
tidak telah menjadi bagian penting yang melekat dalam diri orang-orang dewasa saat ini. Meski fokus pembahasan diletakkan pada Si Kuncung, pembahasan tentang bagaimana media baca anak-anak yang pernah berkembang di Indonesia perlu dibahas dengan singkat agar informasi yang diolah dapat dipahami secara lebih komprehensif.

Tulisan ini merupakan bagian dari penelitian berjudul Majalah Anak-anak Si Kuncung: Relasi Media, Politik dan Kekuasaan Tahun 1979-1988, dimana sumber primer yang digunakan merupakan cetakan-cetakan majalah Si Kuncung serta informasi langsung dari para redaktur dan penulis cerita. Tulisan terkait majalah anak-anak juga tidak dapat dilepaskan dari kajian pers, terutama yang berkembang di era orde baru. Meski majalah anak-anak jarang dilihat sebagai media cetak yang berhubungan langsung dengan unsur kekuasaan, Si Kuncung dalam penelitian ini justru lebih banyak menggunakan pustaka-pustaka bernuansa politik.

\section{Sekilas Bacaan Anak-anak di Indonesia}

“Dalam zaman Belanda kita ada bertaman, dalam zaman Djepangpoen taman kita masih ada. Akan tetapi dalam zaman kita sendiri, di masa kita telah bernegara kembali, telah bertanah air merdeka, taman kita itu tak tentu lagi dimana letaknja. Kakak ta' bertemoe-temoe lagi dengan adik-adik, dan soeara adik-adik jang riang gembirapoen tidak kedengaran lagi. Heran... Mengapa dalam masa sekarang ini, ketika kakak dan adik-adik haroes bersatoe-padoe, harus selaloe berdekatan dan bertoekaran pikiran, taman tempat kita bertjengkerama itu hilang lenjap sadja?"

Kutipan diatas merupakan penggalan bagian pendahuluan edisi pertama majalah Sahabat Anak-anak yang terbit perdana tanggal 14 Juni 1946. Mengapa di tengah gegap gempita kemerdekaan serta kemelut suasana perang, bacaan anakanak menjadi sebuah ruang yang perlu mendapat perhatian khusus? Jika ditelusuri, bacaan anak-anak telah mendapat perhatian khusus jauh sebelum Indonesia memproklamirkan diri menjadi sebuah negara yang berdaulat. Cristantiowati dalam karyanya yang berjudul Bacaan Anak-Anak Tempo Doeloe Tahun 1900-1945 mendeskripsikan perkembangan bacaan anak yang semakin meningkat pasca penerapan politik etis dan pendirian Commissievoor de Inlandsche School en Volkslectuur atau yang kemudian dikenal sebagai Komisi Bacaan Rakyat.

Sejak didirikan 14 September 1908, Commissievoor de Inlandsche School en Volkslectuur atau Komisi Bacaan Rakyat ini bertujuan menyediakan bacaan sehat bagi para murid yang mampu membaca serta memberi pertimbangan kepada Pemerintah Hindia Belanda dalam memilih buku yang akan disebarkan kepada masyarakat. Secara administratif Komisi Bacaan Rakyat bertugas memberikan pertimbangan kepada Departement van Onderwijs en Eeredienst (Departemen Pengajaran) dalam memilih naskah yang akan diterbitkan sebagai buku bacaan dalam pengajaran sekolah. Hal ini diperlukan agar pemerintah dapat mengendalikan bacaan bagi rakyat yang rentan terhadap pengaruh datangnya bacaan dari luar negeri (Alisjahbana, 1992, p. 20). ${ }^{1}$

Kekhawatiran pemerintah dan keputusan untuk berkonsentrasi pada bacaan anak-anak bukannya tanpa alasan. Munculnya semangat kebangsaan beraliran nasionalisme dan sosialisme dianggap semakin mengkhawatirkan, terutama dengan berdirinya Boedi Oetomo tanggal 20 Mei 1908 oleh sekelompok mahasiswa STOVIA,

\footnotetext{
${ }^{1}$ Munculnya semangat kebangsaan melalui bacaan beraliran nasionalisme dan sosialisme dianggap mengkhawatirkan pemerintah pada saat itu, terutama dengan berdirinya Boedi Oetomo pada 20 Mei 1908 oleh sekelompok mahasiswa STOVIA, kemudian ditengarai berasal dari pengaruh bacaan asing.
} 
yang ditengarai berasal dari masuknya pengaruh bacaan asing. Pada 1911, dalam rangka menyalurkan buku-buku terbitan Komisi Bacaan Rakyat sekaligus penyediaan fasilitas yang mampu menunjang kegiatan pengajaran, pemerintah Belanda membangun volksbibliotheek atau Perpustakaan Rakyat. Perpustakaan yang kemudian dikenal dengan nama Taman Pustaka ini menuai respon positif dan mengalami perkembangan yang signifikan.

Pembangunan Taman Pustaka memengaruhi minat baca sekaligus meningkatkan permintaan terhadap buku-buku bacaan, terutama buku bacaan anak. Komisi Bacaan Rakyat lalu menghadapi kesulitan akibat birokrasi yang berbelit-belit dan menghambat penerbitan bacaan. Demi peningkatan produksi, maka berdasarkan Gouvernements Besluit No. 63 tanggal 22 September 1917, dibentuklah Balai Pustaka yang mampu memangkas proses penerbitan dengan menjadi lembaga mandiri dan bertugas secara khusus memenuhi kebutuhan Taman Poestaka. Balai Pustaka lalu secara konsisten menerbitkan karya-karya sastra yang menarik, termasuk karya-karya dengan sasaran pembaca anak-anak dan remaja. Meski banyak buku-buku merupakan karya terjemahan maupun saduran, Balai Pustaka setidaknya mampu menggairahkan dunia bacaan anak-anak kala itu. Karya Merari Siregar, Si Djamin dan Si Djohan (1918) yang merupakan saduran dari karya Oliver Twist atau novel Tom Sawyer karya Mark Twain yang mampu meraih popularitas dalam masa yang cukup panjang.

Ruang bacaan anak-anak juga mendapat perhatian semasa gejolak Perang Dunia II. Pemerintahan Balatentara Dai Nippon yang berhasil menguasai HindiaBelanda setelah Pemerintah Belanda menyerah tanpa syarat tanggal 8 Maret 1942, dengan segera menutup sekolah-sekolah dengan maksud membendung pengaruh Barat di wilayah Indonesia. Seluruh buku dan bacaan terbitan Belanda dilarang dan seluruh percetakan diambil alih (Christantiowati, 1993, p. 93). ${ }^{2}$ Sekolah Desa diganti dengan nama Sekolah Pertama dengan masih menggunakan bahasa daerah sebagai bahasa pengantar, sedangkan Sekolah Tingkat Kedua, HIS dan sekolah lainnya digabung dengan istilah baru yaitu Sekolah Rakyat dengan bahasa pengantar bahasa Melayu-Indonesia yang sudah cukup populer pada masa itu.

Balai Pustaka, yang kemudian berganti nama menjadi Kokumin Tosyokyoku, diberi tugas untuk segera menerbitkan buku-buku pelajaran baru bagi sekolahsekolah yang akan dibuka. Buku-buku yang mendapat prioritas penerbitan merupakan buku-buku terkait kebudayaan Jepang, Bahasa Jepang dan Teknik-teknik Dasar Pertahanan Diri (Christantiowati, 1993, pp. 94-95). Kokumin Tosyokyoku juga menerbitkan ulang buku-buku populer sebelumnya dengan judul baru dan beberapa revisi penggunaan bahasa serta menerima karangan dan tulisan karya pembaca.

Selama periode Pemerintahan Militer Jepang, tidak banyak buku-buku baru yang diterbitkan. Majalah atau surat kabar bahkan diawasi dan beberapa dimatikan. Hanya Asia Raya satu-satunya surat kabar di Jakarta dan majalah Panji Pustaka yang diperbolehkan terbit (Jassin, 1992, pp. 59-60). Bacaan anak-anak kemudian diruangkan dalam lampiran Taman Kanak-Kanak, yang diterbitkan melalui majalah Panji Pustaka. Hingga masa kemerdekaan yang dipenuhi dengan gejolak, ruang baca untuk anak-anak perlahan semakin menyusut lalu kemudian menghilang.

\section{Si Kuncung: Lahirnya Bacaan Sekolah Rakyat}

Pada 1955, setelah Pemilu pertama selesai diselenggarakan, jumlah penerbitan mingguan, bulanan dan berkala membengkak hingga mencapai 351 judul, dari yang sebelumnya pada 1950 hanya berjumlah 226 judul (Junaedhie, 1995, p. 24). Surat

\footnotetext{
${ }^{2}$ Seluruh sekolah baru diizinkan untuk dibuka kembali pada 29 April 1942, setelah melalui proses pelaporan pembukaan sekolah pada pemerintah setempat.
} 
kabar dan majalah tumbuh dimana-mana tanpa harus meminta izin terlebih dahulu. Publik bebas mengutarakan pendapat dan kemauan masing-masing.

Sudjati SA, wartawan Pedoman, berinisiatif menggunakan peluang tersebut dengan menerbitkan majalah anak-anak Si Kuncung untuk menyediakan ruang baca anak-anak yang lama hilang. Pedoman sendiri merupakan sebuah surat kabar yang berasosiasi dengan Partai Sosialis Indonesia (PSI), sebuah partai kecil anti komunis yang vokal dan beberapa kali bersitegang dengan pemerintah (Hill, 2011, p. 101). Berdasar pada pengalaman menulis berita serta keterlibatannya dalam penerbitan cerpen sastra bulanan "Kisah" bersama HB Jassin, Idrus, dan M. Balfas, Sudjati mulai menulis cerpen untuk anak-anak. Berkantor di Jalan Madura No. 2, Menteng, Jakarta, Sudjati mulai mengumpulkan rekan-rekan sesama wartawan dan beberapa sastrawan untuk membantunya mengasuh Si Kuncung. Pengarang-pengarang yang kemudian terlibat sebagian besar berasal dari majalah Kisah, Mimbar Indonesia dan Siasat. Si Kuncung lalu tampil dengan membawa idealisme jurnalis dan sastrawan muda yang prihatin terhadap kurangnya bacaan bermutu bagi anak-anak.

Pertemuan Sudjati dengan Soekanto SA menjadi langkah awal yang positif bagi Si Kuncung. Semula, Soekanto menolak dengan alasan tidak terbiasa menulis cerpen anak-anak. Cerita anak-anak dianggap sebagai bagian dari pekerjaan guru. Selain itu, keharusan untuk berkomunikasi dengan pesan moral yang disampaikan dikhawatirkan dapat membatasi pengarang dalam mengekspresikan pikiran dan perasaan. Namun pada akhirnya, kesadaran tentang pentingnya sastra bagi anakanak meluluhkan hati Soekanto. Cerita anak-anak adalah bagian dari sastra, dan sastra adalah sastra. Soekanto SA pun menjadi salah seorang penulis inti yang mengasuh Si Kuncung. Soekanto yang terinpirasi oleh kedatangan seorang anak gadis bernama Gustini di kantor redaksi Si Kuncung di Jalan Madura No. 12 Jakarta, lalu menciptakan serial cerpen berjudul Hari-hari Bersama Gustini. ${ }^{3}$ Cerpen yang bercerita tentang anak gadis yang cerdas ini menjadi cerpen khas Si Kuncung dan mengisi edisi Si Kuncung hingga 1958. ${ }^{4}$ Selain Soekanto, nama lain yang muncul dalam tahun-tahun awal Si Kuncung antara lain, Trim Sutidja, K. Usman, Mansur Samin, Julius Sijaranamual, Darmosusanto, Surtiningsih W.T., S.Toer, B.S.Tron, Suyono HR, HB Soepiyo, dan Rys Therik.

Sistem redaksi dalam penerbitan Si Kuncung menggunakan sistem yang sederhana. Terdapat bagian redaksi, karyawan, ilustrator, dan penulis lepas (Wawancara dengan Eddy Herwanto, 10 Agustus 2015). Pada terbitan tahun pertama dan kedua, Sudjati SA sebagai pemimpin redaksi dibantu oleh Muharijo, Riardi, Soekanto, dan Suyono HR sebagai redaksi. ${ }^{5}$ Bagian ilustrasi diisi oleh Ekana Siswoyo, Hidayat Said, Ipe Ma'ruf, dan beberapa karyawan lain yang membantu percetakan dan penjualan.

Penulis yang berkontribusi mengirimkan tulisan dibayar sesuai dengan cerpen atau tulisan yang diterima. Hal demikian membuat penulis dalam Si Kuncung sering kali berganti-ganti dan berbeda dalam tiap edisi. Meski demikian, terdapat beberapa nama yang konsisten mengirimkan tulisan dan menjadi penulis tetap $\mathrm{Si}$ Kuncung selama bertahun-tahun.

Berdasar nama-nama penulis yang muncul dibalik cerita-cerita Si Kuncung, Sudjati tampaknya memilih penulis-penulis yang tidak terlibat dalam perseteruan dunia sastra yang saat itu tengah terjadi. Meski tidak secara langsung menyatakan

${ }^{3}$ Jalan Madura kini berubah menjadi Jl. Moh. Yamin, Menteng, Jakarta Pusat.

${ }^{4}$ Serial "Hari-hari bersama Gustini" berakhir pada edisi No. 8 tahun 1958, dimana Gustini diceritakan telah mendapat beasiswa untuk melanjutkan Sekolah Menengah dan selesai melewati ujian akhir di Sekolah Rakyat.

${ }^{5}$ Nama-nama tersebut diperoleh dari catatan redaksi Si Kuncung No.1 tahun 1957 serta hasil beberapa wawancara. 
diri sebagai majalah anti-komunis, belum ditemukan catatan terkait keterlibatan sastrawan maupun penulis Lekra atau gerakan kiri lainnya dalam cerpen-cerpen $S i$ Kuncung. Sebagian besar merupakan rekan sastrawan, jurnalis dari Siasat, Pedoman atau pengarang muda yang baru menjejaki dunia kepengarangan. ${ }^{6}$ Sudjati tampak menempatkan dunia anak-anak sebagai dunia yang paralel dari dunia politik dengan tetap memberikan edukasi nilai dan norma dalam cerita-ceritanya. Keputusan untuk menyajikan karya tanpa keberpihakan yang mencolok menempatkan Si Kuncung pada jalur aman dunia penerbitan pada saat itu.

Edisi perdana Si Kuncung yang terbit 1 April 1956 menjadi terbitan fenomenal karena untuk kali pertama kali majalah ini dicetak ulang untuk satu nomor terbitan perdana (Soekanto, 1986, pp. 340-345). Tampilan depan diisi dengan sebuah logo khas Si Kuncung dan sebuah cerita berjudul "Pesta Kacang" karya Darmosusanto. Halaman selanjutnya menampilkan lagu karya Pak Kasur yang berjudul Naik Delman, yang juga dengan cepat meraih popularitas.

Pada halaman depan bagian atas, Si Kuncung menggunakan gambar berupa lima anak-anak yang berbaris dengan menggunakan topi kertas berbentuk kerucut dan anak terakhir yang pakaiannya digigit seekor anjing kecil. Mereka membawa mainan, alat musik, dan bendera bertuliskan Si Kuncung dengan ekspresi gembira. Bendera tersebut memiliki semboyan Si Kuncung yang bertuliskan "Si Kuntjung Batjaan Sekolah Rakjat". Gambar ini kemudian menjadi ciri khas Si Kuncung, baik dalam kolom iklan maupun dalam ragam terbitan Si Kuncung yang lainnya.

Kata "kuncung" dalam bahasa Jawa berarti gombak, atau dalam bahasa Indonesia berarti semacam jambul (pada ayam, burung dan bunga); jambak (rambut di dahi pada kuda); rambut di atas dahi yang ditinggalkan sehabis dipangkas (Kamus Besar Bahasa Indonesia, 2018). Pada logo, tampak anak yang berjalan paling depan memiliki "kuncung" yang menonjol di sela topi kerucutnya sehingga dapat berarti "anak yang memiliki model rambut kuncung". Namun selain itu, kelima anak yang berbaris tersebut juga menggunakan topi kerucut yang juga disebut " topi kuncung", sehingga "si kuncung" juga dapat berarti "anak yang menggunakan topi kuncung atau kerucut".

Penggunaan istilah "kuncung" sendiri lebih dikenal dalam masyarakat secara umum terutama masyarakat pedesaan di daerah Jawa. ${ }^{7}$ Hal ini memberikan kesan kedekatan antara majalah Si Kuncung dengan masyarakat. Selain itu, penyajian konten cerita dalam Si Kuncung yang didominasi oleh cerita-cerita dari pelosokpelosok daerah di Indonesia membuat Si Kuncung kental dengan aura anak-anak pedesaan.

Berdasar Surat Izin Terbit yang diperoleh pada 1957, Si Kuncung tersebar luas hampir di seluruh Jakarta dan beberapa kota besar di Jawa. Respon positif dan tingginya penjualan membuat Si Kuncung tetap terbit dengan harga yang masih terjangkau, meski situasi perekonomian sedang memasuki masa-masa krisis. Bahkan, banyaknya karangan yang masuk membuat Si Kuncung mampu membuka peluang baru dengan menerbitkan Si Kuncung Istimewa, semacam edisi spesial yang terbit sebulan sekali.

Pada 1960, Sudjati menyatakan bahwa Si Kuncung Istimewa telah membantu meningkatkan penjualan hingga mencapai 800.000 pembaca sejak pertama kali terbit. Si Kuncung Istimewa dianggap mampu menarik minat pembaca Si Kuncung kepada lingkup pasar yang lebih luas (Si Kuncung Istimewa, 1960). Si Kuncung semakin ramai digemari dan banyak menerima karangan. Diluar penerimaan karangan melalui pos,

\footnotetext{
${ }^{6}$ Hingga penelitian ini disusun, belum ditemukan adnaya keterlibatan penulis ataupun sastrawan Lekra dalam penerbitan Si Kuncung.

${ }^{7}$ Terdapat sebuah cerita yang terkenal yaitu Si Kuncung dan Si Bawuk yang beredar di kalangan anak-anak di Jawa (Wawancara dengan Seto Mulyadi, 22 Februari 2015)
} 
banyak penulis muda yang tertarik untuk menuliskan cerita pendek secara reguler. Banyaknya persediaan tulisan, terutama cerpen, memicu produktifitas Si Kuncung untuk menerbitkan varian baru berupa buku kecil berisi kumpulan cerpen.

\section{Gejolak Politik dan Perubahan Sistem}

Pada 30 September 1965, Indonesia dikejutkan dengan peristiwa penculikan dan pembunuhan jenderal-jenderal yang konon dilatarbelakangi oleh pemberontakan Partai Komunis Indonesia (Ricklefs, 2008, pp. 598-600). ${ }^{8}$ Peristiwa tersebut turut mengguncang dunia perpolitikan Indonesia yang berakhir pada penyerahan kekuasaan dari Presiden Soekarno kepada Jenderal Soeharto melalui surat kuasa yang dikenal sebagai Supersemar (Surat Perintah Sebelas Maret) 1966.

Orde Baru lahir dengan semangat membedakan diri dengan "Orde Lama", sebuah istilah yang ditujukan pada pemerintahan Soekarno sebagai rezim yang telah berlalu. Kebijakan dan haluan politik yang diambil juga bertolak belakang dengan kebijakan pemerintah sebelumnya. Orde Baru yang inti dukungannya terdiri atas faksi militer kemudian sering kali identik dengan rezim militer (Alkatiri, 2014, pp. 155-169). Pemerintah Orde Baru dengan segera mencanangkan Empat Tahap Strategi Politik yang secara langsung memengaruhi kebijakan di berbagai bidang. Empat tahapan tersebut adalah penghancuran PKI beserta ideologi Marxisme dari kehidupan politik bangsa, konsolidasi pemerintahan dan pemurnian Pancasila dan UUD 1945, menghapuskan atau menghilangkan dualisme kepemimpinan nasional, serta mengembalikan stabilitas politik dan merencanakan pembangunan (Djojonegoro, 1996, p. 149).

Pada tahun-tahun pertama pemerintahannya, Presiden Soeharto menargetkan dua prioritas penting, yaitu pengembalian stabilitas dan keamanan negara serta pengendalian inflasi dan penurunan harga bahan pokok. Stabilitas dan keamanan negara dikendalikan dengan "pembersihan" unsur-unsur perusak dan pengganggu dalam seluruh aspek dan lapisan masyarakat. ${ }^{9}$ Hal ini kemudian menjadi salah satu ciri khas model pemerintahan Orde Baru, pemerintah menempati posisi sebagai pihak baik yang selalu benar dengan pihak lain yang berbeda haluan sebagai musuh, provokator, ekstrimis, anti-Pancasila dan anti-pembangunan (Djojonegoro, 1996, p. 149).

Berdasar alasan stabilitas negara dan penegakan Pancasila, pemerintah Orde Baru dengan jeli mengawasi dan mengendalikan media informasi yang berhubungan secara langsung dengan masyarakat. Pemerintah mengambil tindakan perubahan di segala bidang, termasuk dalam dunia pers dan percetakan. Pada 1969, permasalahan bacaan anak-anak menjadi tema yang menarik perhatian. Hal ini tampak dari Dewan Perwakilan Rakyat yang menyatakan masalah bacaan anak sebagai masalah nasional yang perlu segera ditangani. Resolusi yang diprakarsai oleh Nyonya Sukahar ini mendapat reaksi positif dari anggota dewan dan juga presiden (Djojonegoro, 1996, p. 149). Pada tahun yang sama, segera dibangun Pusat Perpustakaan Anak-anak di Balai Pustaka dengan dasar pertimbangan penyediaan bacaan bermutu bagi anakanak (Soekanto, 1986, p. 352).

Perhatian yang diberikan secara langsung oleh presiden pada pihak Si Kuncung dengan segera turut membesarkan nama Si Kuncung. Pada awal 1970-an, Si Kuncung kedatangan penulis-penulis muda berbakat, antara lain Soerasono, Eddy Herwanto dan M. Sobary. Mereka merupakan pelajar perantauan di Jakarta yang

\footnotetext{
${ }^{8}$ Terdapat berbagai macam versi terkait pelaku peristiwa 30 September 1965, namun demikian pemerintah menetapkan peristiwa tersebut didalangi oleh PKI.

${ }^{9}$ Unsur-unsur perusak dan pengganggu lebih ditujukan kepada kelompok pembuat onar atau seringkali merujuk pada anggota maupun simpatisan PKI setelah penetapan PKI sebagai partai terlarang.
} 
semasa kecil adalah pembaca setia Si Kuncung. Kebiasaan membaca Si Kuncung sejak kecil membuat mereka dapat beradaptasi dengan cepat dalam hal menulis tematema serupa. Gaya penceritaan khas Si Kuncung yang sederhana namun sarat pesan moralpun dapat dilanjutkan melalui tulisan-tulisan mereka sebagai generasi kedua Si Kuncung (Wawancara dengan Soerasono, 15 Agustus 2015).

Pada 7 Desember 1973, pemerintah menerbitkan Instruksi Presiden tentang Program Bantuan Pembangunan Sekolah Dasar. Inpres tersebut menyebutkan bahwa dalam rangka mempercepat peningkatan kesempatan belajar di Sekolah Dasar, khususnya bagi anak-anak yang berumur 7-12 tahun, perlu diadakan penambahan gedung-gedung sekolah dasar baru serta peningkatan anggaran bagi rencana pembangunan pendidikan sekolah dasar yang dimulai dalam Repelita II. ${ }^{10}$ Berdasar petunjuk pelaksanaan program bantuan pembangunan sekolah dasar, yang dimaksud dengan Program Bantuan Pembangunan Sekolah Dasar adalah bantuan langsung atas beban Anggaran Pendapatan dan Belanja Negara 1973/1974 untuk pembangunan gedung-gedung sekolah dasar, yang dilengkapi dengan penyediaan guru, perabot sekolah, buku-buku pelajaran pokok, dan buku bacaan kanak-kanak untuk perpustakaan.

Berdasar Inpres pertama tersebut, pemerintah menyediakan bacaan anakanak melalui pembelian terhadap bacaan anak-anak yang telah diterbitkan. Pemerintah membeli sejumlah judul buku bacaan anak-anak dengan oplah masingmasing telah ditentukan kepada penerbit-penerbit yang memproduksi bacaan anakanak. (Sutidja, 1984). Pada tahap pertama, dibeli sekitar 300 judul dengan oplah diatas 24.500 eksemplar. Buku-buku tersebut kemudian disebar di tiga rayon, dengan prioritas daerah pedesaan dan perkotaan yang penduduknya berpenghasilan rendah. ${ }^{11}$ Hingga 1981, telah dibeli lebih dari 2.500 eksemplar dari 300 judul setiap tahun, kecuali pada 1982 dilakukan pengecilan jumlah pembelian buku.

Pasca-peristiwa Malari, beragam media cetak dan surat kabar memperbaharui Surat Izin Cetak dan Surat Izin Terbit, begitu pula dengan Si Kuncung. Namun demikian, Si Kuncung yang tidak mengala)mi masalah dalam proses penyegaran, justru mendapat dukungan yang semakin besar dari pemerintah. Pada 1976, berdasar pelaksanaan Inpres atas pembelian bacaan anak-anak, Si Kuncung turut dipesan oleh pemerintah untuk kemudian disebar ke seluruh pelosok Indonesia (Wawancara dengan Soekanto, 20 Agustus 2015). Penyebaran ini sangat menguntungkan Si Kuncung dan secara otomatis mengubah banyak hal, diantaranya model pendistribusian, tampilan fisik, dan konten dalam majalah Si Kuncung.

Pada 1979, Si Kuncung mengubah tagline yang semula berbunyi "Bacaan Sekolah Dasar" menjadi “ Majalah Pendidikan dan Kebudayaan”. Tagline baru yang diusung membuat Si Kuncung berbeda dari majalah anak-anak pada umumnya. ${ }^{12}$ Si Kuncung tidak lagi dilihat sebagai majalah hiburan biasa, melainkan media bacaan anak yang mengandung informasi dan ilmu pengetahuan. "Majalah anak-anak Si Kuncung mempunyai pola dasar pemikiran tersendiri, yakni membaca sambil berpikir demi peningkatan daya nalar pada si anak, agar potensi mereka bisa berkembang. Jadi cukup jelas bahwa Si Kuncung bukan majalah hiburan, melainkan majalah pendidikan dan kebudayaan" (Sudjati, 1980).

\footnotetext{
${ }^{10}$ Instruksi Presiden Republik Indonesia Nomor 10 Tahun 1973.

${ }^{11} 100$ buku untuk setiap rayon.

${ }^{12}$ Pada 2004, Pusat Bahasa Departemen Pendidikan Nasional menerbitkan buku berjudul Peran Majalah Hiburan tahun 1970-1980 dalam Perkembangan Kesusastraan Indonesia Modern yang merilis daftar majalah-majalah hiburan yang terbit selama rentang 1970-1989. Rilisan tersebut tidak mencantumkan Si Kuncung sebagai bagian dari majalah hiburan yang pernah beredar, berbeda dengan majalah Kawanku, Bobo dan beberapa majalah anak-anak yang terbit setelah 1970.
} 
Istilah pendidikan dan kebudayaan pada dasarnya sejalan dengan semangat program pemerintah dalam dunia pendidikan. Daoed Joesoef, Menteri Pendidikan dalam periode 1978-1983, menyatakan bahwa pendidikan merupakan bagian dari kebudayaan, dan keduanya tidak dapat dipisahkan (Sardiman dan Yuliantri, 2012). Pendidikan dan kebudayaan dapat menjadi poros penting dalam pembangunan generasi muda, sehingga perlu digalakkan dan didukung baik di sekolah maupun di luar lingkungan sekolah dan dalam kehidupan sehari-hari.

Pembangunan pendidikan dalam masa Orde Baru mengacu pada pembentukan manusia Pancasila, manusia pembangunan yang tinggi mutunya dan mampu mandiri, serta memberikan dukungan perkembangan kepada masyarakat yang terwujud dalam ketahanan nasional yang tangguh. Sistem ketahanan nasional yang tangguh secara otomatis dapat membendung generasi muda dari ajaran ataupun ideologi asing yang bertentangan dengan asas Pancasila (Djojonegoro, 1996, p. 149). Berdasar pada pengembangan mutu pendidikan dan kebudayaan tersebut, maka perubahan tagline Si Kuncung mengandung makna dan tanggung jawab besar. Si Kuncung telah menempatkan diri sebagai media yang ikut berpartisipasi dalam program pembangunan pendidikan nasional.

Apresiasi pemerintah terhadap majalah Si Kuncung terus meningkat hingga pada 1980 Sudjati SA mendapat Piagam Hadiah Pendidikan. Penghargaan dari presiden Soeharto yang ditanda tangani oleh Menteri Pendidikan dan Kebudayaan Daoed Joesoef tersebut diberikan kepada Sudjati atas jasanya terhadap negara sebagai "Perintis Majalah Kanak-Kanak dan Sudah Berprestasi Selama 25 tahun". Hadiah tersebut diberikan atas dasar Keputusan Presiden Republik Indonesia Nomor 23 tahun 1976 tanggal 7 Mei 1976 dan Keputusan Menteri Pendidikan dan kebudayaan nomor 0265/M/1977 tanggal 13 Juli 1977.

Pada ulangtahunnya yang ke 27, Si Kuncung bahkan merayakannya dengan melakukan kunjungan ke kediaman menteri pendidikan dan memberikan bundel Si Kuncung sebagai kenang-kenangan sekaligus meminta secara langsung Menteri Daoed Joesoef untuk memberi pesan bagi para pembaca setia Si Kuncung. Kedekatan Si Kuncung dengan departemen dan menteri pendidikan secara langsung tidak hanya berhenti sampai di situ. Setelah pergantian menteri pada 1983, dimana Nugroho Notosusanto menjabat sebagai Menteri Pendidikan, Si Kuncung tetap berperan aktif dalam menjalin hubungan baik dengan pihak pemerintah.

Pada 1980, pemerintah melalui Dirjen Pendidikan menerbitkan seri cerita Pedoman Penghayatan dan Pengamalan Pancasila (P4) dalam setiap terbitan Si Kuncung. Rubrik ini berisi cerita-cerita yang mampu menggugah semangat pancasila, dimana di setiap cerita tersurat pesan-pesan moral pancasila. Pada tahun yang sama, pemerintah juga turut mensosialisasikan program-programnya melalui rubrik-rubrik Si Kuncung. dr. Suwardjono Surjaningrat selaku Menteri Kesehatan/Kepala Badan Koordinasi Keluarga Berencana Nasional (BKKBN) bersama Si Kuncung lalu menerbitkan seri kependudukan yang berisi cerita maupun artikel terkait ledakan populasi penduduk dan pentingnya program keluarga berencana.

"Usaha untuk menerbitkan tulisan seri kependudukan untuk anak anak tingkat sekolah dasar ini merupakan suatu usaha yang sangat penting yang memcerminkan rasa tanggungjawab kita semua terhadap hari depan generasi mendatang. Hal ini sejalan dengan usaha kegiatan pendidikan kependudukan di sekolah dan di luar sekolah yang telah dimulai sejak awal tahun tujuh puluhan, diharapkan dengan ini diberikan informasi mengenai masalah kependudukan kepada anak anak kelas V dan VI yang akan memasuki usia remaja dalam lima atau enam tahun mendatang" (Si Kuncung, 1980). 
Penggunaan dasar pemikiran bahwa anak-anak akan menginjak remaja lima hingga enam tahun ke depan, membuat pendidikan terkait keluarga berencana untuk anak-anak setingkat Sekolah Dasar terkesan dipaksakan. Terlebih lagi, dimuatnya rubrik tersebut justru mengurangi ruang cerita dan kreasi bagi anakanak. Namun demikian, pemerintah tetap dengan gencar melaksanakan sosialisasi program-programnya melalui Si Kuncung.

Pada 1 oktober 1981, Si Kuncung menambah muatan Seri Diorama Museum ABRI Satriamandala. Serupa dengan penerbitan seri kependudukan dan penerbitan seri P4, Seri Diorama juga dimulai dengan sambutan dari pihak pemerintah. Melalui sambutan tertulis oleh Kepala Pusat Sejarah ABRI Departemen Pertahanan Keamanan, Brig. Jen. Prof. Dr. Nugroho Notosusanto dan Direktur Jemderal Pendidikan Dasar dan Menengah Prof. Darji Darmodiharjo, SH, diorama tersebut membawa suatu misi dan menitikberatkan pada kejadian kejadian yang penting, dalam hal ini peristiwa-peristiwa dalam perang kemerdekaan 1945-1949 (Si Kuncung, 1981). Sambutan yang dimuat dalam setiap serial baru lalu menjadi ciri khas yang terus berlangsung hingga 1988.

Selain seri yang menampilkan semangat kebangsaan dan nasionalisme dan sosialisasi program, Si Kuncung juga kebanjiran tulisan dan seri karangan ilmiah yang berjalan seiring dengan kebijakan pemerintah. Pada 2 Mei 1984, Dirjen Pendidikan Dasar dan Menengah kembali menerbitkan seri baru, yaitu seri karangan ilmiah populer tentang uraian geologis proses terjadi dan terbentuknya pulau pulau serta laut di bumi nusantara Indonesia dengan judul "Indonesia Tanah Airku". Penerbitan seri ilmiah yang disusun oleh Soewarno Darsoprajitno tersebut bertepatan dengan dimulainya perubahan penyempurnaan penggambaran peta Indonesia, dari penggambaran kumpulan pulau pulau yang dipisahkan oleh lautan menjadi penggambaran kumpulan pulau pulau yang justru disatukan oleh lautan. Cara pandang tersebut dikenal dengan "Wawasan Nusantara".

Konsepsi Wawasan Nusantara yang disajikan dalam Si Kuncung memberi manfaat yang cukup besar bagi anak-anak. Hal ini didasarkan pada konsepsi Wawasan Nusantara yang juga dicantumkan dalam kurikulum pelajaran ilmu bumi sehingga bacaan melalui Si Kuncung dapat secara langsung membantu anak-anak dalam memahami pelajaran sekolah. Terdapat pula seri karangan lain karya Prof. Dr. Ir. Otto Soemarwoto yang berjudul "Pengelolaan Air dan Sungai". Seri karangan ini disajikan dengan tujuan melengkapi pengetahuan tentang lingkungan hidup yang pada saat itu belum diterapkan dalam kurikulum sekolah dasar.

"Pada tingkat sekolah dasar ini anak didik tidak perlu memperoleh mata pelajaran khusus tentang lingkungan hidup. Untuk ini beban pelajaran yang diterima murid murid menjadi terlalu berat. Yang penting adalah menanamkan wawasan penglihatan lingkungan kepada anak didik melalui cara mengajar (dedaktika) berbagai ilmu, seperti ilmu pengetahuan alam, ilmu pengetahuan sosial, pendidikan moral pancasila, agama dan olahraga kesehatan. Mata pelajaran ini bisa diajarkan dengan menggunakan contoh, antara lain dengan mengutip cerita Prof. Otto Soewarmoto tentang daerah aliran sungai ini. Dengan begitu ilmu masuk dengan wawasan penglihatan lingkungan".

Selain seri karangan ilmiah, Si Kuncung juga menyajikan Kisah Wiraswasta, yang menampilkan profil-profil pengusaha sukses dan ragam usahanya (Si Kuncung, 1980). Pengusaha yang ditampilkan pada umumnya merupakan pengusahapengusaha di bidang pertanian dan perikanan. Rubrik ini juga seringkali menyediakan tips dan resep singkat dalam membuat sebuah produk yang mudah, menarik dan ramah lingkungan. 
Halaman Si Kuncung yang semula berjumlah 36 lalu menyusut menjadi 32 halaman. Si Kuncung terbit dengan total 32 halaman dianggap belum mencukupi untuk menampung semua rubrik tersebut. Oleh karena itu, beberapa rubrik disajikan secara berselang setiap edisi genap dan ganjil. Seperti halnya rubrik Kebunku yang dimuat berselang dengan Seri Ekologi, serta rubrik Seri Karangan Ilmiah yang disajikan hanya setiap dua minggu sekali. Selain itu, Si Kuncung juga kerap menyajikan program-program pemerintah yang sedang berjalan, seperti kegiatan koperasi, transmigrasi dan program perumahan rakyat.

Lembaran iklan komersilpun semakin menyusut dan hanya tersedia dalam dua kolom kecil. Iklan yang ditampilkan sebagian besar merupakan produk negara atau iklan resmi dari lembaga pemerintah tertentu. Bahkan, ketika pemerintah tengah gencar melancarkan program pertambangan dan penjualan minyak, Si Kuncung turut berpartisipasi dengan menyajikan Seri Pertambangan yang diterbitkan dua pekan sekali (Si Kuncung, 1979). Seri Pertambangan yang menampilkan proses pertambangan dan manfaatnya bagi bangsa Indonesia tersebut didukung sepenuhnya oleh Pertamina.

\section{Analisa: Membaca Akhir Cerita Si Kuncung}

Anak-anak menanggung beban masa depan, sehingga perencanaan jangka panjang perlu mempertimbangkan keberadaan anak-anak. Perhatian pemerintah terhadap Si Kuncung tampak serius. "Media massa, jadi alat penting dalam memelihara dan membantu beranakpinaknya legitimasi Orde Baru. Ini bisa dipahami, sebagai lembaga budaya, pers Indonesia telah mengalami masa-masa keji penuh badai dalam perjalanan sebuah negara" (Hill, 2011, p. 34).

Kekhawatiran pemerintahan Soeharto tampaknya bukan hanya sebatas pada lembaga media atau pers. Pendidikan melalui kurikulum, tayangan, tontonan dan bacaan anak-anak menjadi bidang khusus yang terus mengalami pengawasan. ${ }^{13} \mathrm{Si}$ Kuncung yang berperan sebagai media massa sekaligus penghubung yang ideal dengan dunia anak-anak secara otomatis menjadi agen penting yang perlu diperhatikan dan diawasi.

Pemilihan Si Kuncung sebagai media yang mendapat "perhatian" khusus bukan suatu kebetulan yang terjadi secara acak. Si Kuncung adalah satu-satunya majalah anak-anak yang mampu bertahan lebih dari sepuluh tahun dan telah membentuk hegemoni kecil melalui pembaca-pembacanya dari pelosok-pelosok daerah di Indonesia. Hegemoni yang telah terbentuk serta kesempatan untuk memonopoli informasi membuat Si Kuncung menjadi media komunikasi ideal untuk mensosialisasikan dan"menanamkan" nilai-nilai yang dikendaki oleh pihak penguasa.

Padatnya rubrik yang disajikan menggeser kehadiran cerpen-cerpen kiriman pembaca dan juga penulis tetap dalam Si Kuncung. Dalam satu terbitan, hanya dapat ditemui dua atau tiga cerita pendek sepanjang satu halaman karangan pembaca ataupun penulis lepas. Rubrik-rubrik yang khusus yang disajikan tidak dapat ditulis oleh sembarang orang, melainkan oleh tokoh tertentu seperti perwakilan badan atau lembaga terkait serta ilmuwan yang sudah dikenal masyarakat luas. Selain meningkatkan profesionalisme dalam menyampaikan ilmu pengetahuan, penulis yang selektif akan meminimalisir adanya pengaruh atas bacaan yang dianggap kurang baik.

Seri Karangan Ilmiah yang semakin mendominasi membuat banyaknya penulis ilmiah yang terlibat dalam penerbitan Si Kuncung. Kualifikasi yang tinggi serta gaya bahasa ilmiah yang digunakan membuat Si Kuncung bukan lagi majalah anak-anak yang bersifat menghibur dan rekreatif. Penulisan rubrik-rubrik khusus tersebut

\footnotetext{
${ }^{13}$ Terutama terkait peristiwa 1965 dan peristiwa di sekitar proses peralihan kekuasaan.
} 
melibatkan banyak tenaga ahli yang sudah diakui kemampuannya. “...karena para sarjana ini mempunyai pemikiran akademis, maka tidak ada salahnya bila dijabarkan secara sederhana anak-anak dapat mengikutinya. Toh, para sarjana ini sudah menguasai ilmunya hingga rasanya tidak mungkin melakukan kesalahan" (Kompas, 1980). Selain para sarjana, pengisi majalah Si Kuncung juga datang dari kalangan profesor. Prof. Andi Hakim Nasution dari IPB dengan senang hati mengisi rubrik matematika. Begitu juga dengan Prof. Teuku Jacob dari UGM yang menyajikan rubrik arkeologi dalam Serial Manusia Purba Indonesia, serta Prof. Otto Soemarwoto yang menulis rubrik lingkungan hidup (Kompas, 1980).

Peningkatan kualitas konten Si Kuncung secara keilmuan, diharapkan mampu mempertahankan bahkan meningkatkan penjualan Si Kuncung. Pandangan terkait "bacaan yang bagus dan berkualitas akan senantiasa diminati" membuat Si Kuncung dan pihak pemerintah terus berupaya meningkatkan mutu pendidikan dalam ceritacerita Si Kuncung. Di lain pihak, ramainya penulis ilmiah yang terlibat justru mengurangi komposisi penulis cerita dengan tema yang lebih lepas. Sebagian besar penulis yang sebelumnya mengisi cerpen Si Kuncung kini beralih mengisi majalah maupun surat kabar lain. Selain itu, ruang yang disediakan untuk penulis juga semakin terbatas sehingga karangan kiriman pembaca, khususnya anak-anak, mulai sulit ditemukan. Kehilangan banyak penulis lepas berakibat pada menurunnya regenerasi Si Kuncung. Hal ini membuat Si Kuncung tidak lagi mampu mengikuti perkembangan jaman, terlebih dengan kehadiran kompetitor yang semakin kuat. Pembaca anak-anak yang disuguhkan materi ilmiah yang cenderung serupa dengan pelajaran di sekolah perlahan kehilangan minat dan beralih ke majalah lain.

Pada 1988, Sudjati kembali memperoleh lencana penghargaan dari Presiden Soeharto meski kepemimpinan Si Kuncung telah dialihkan pada putra sulungnya, Indrawan Sudjati (Sang Perintis Kempis, 2015). Sudjati juga memperoleh penghargaan dari ibu negara Tien Soeharto sebagai Tokoh Pencinta Anak. Sambutan-sambutan dari berbagai tokoh nasionalpun membanjiri lembar edisi khusus ulang tahun $S i$ Kuncung yang ke-32. Hubungan yang erat dengan pemerintah ternyata berbanding terbalik dengan posisi Si Kuncung di pasaran. Penjualan terus menurun bahkan membuat Si Kuncung hanya mampu bertahan dengan biaya dari pemerintah (Wawancara dengan Soekanto, 20 Agustus 2015). Setelah 1988, Si Kuncung tidak lagi ditemukan di pasaran majalah anak-anak Indonesia. Si Kuncung tergeser oleh majalah-majalah anak lain yang muncul belakangan, bahkan semakin tak terdengar dan kehilangan ruang.

\section{Simpulan}

Sejatinya, Si Kuncung telah berhasil meninggalkan catatan mengesankan, baik bagi para pembacanya maupun dalam sejarah bacaan anak di Indonesia. Sama halnya dengan posisi Si Kuncung dalam penelitian ini. Si Kuncung sebagai sebuah majalah, bisa jadi hanya merupakan satu dari ratusan bacaan anak-anak yang pernah ada di Indonesia. Akan tetapi, setidaknya Si Kuncung merupakan majalah pertama dan mungkin satu-satunya yang menjalin relasi sangat dekat dengan pemerintah di masa Orde Baru. ${ }^{14} \mathrm{Hal}$ ini tentu membuat Si Kuncung layak untuk memiliki ruang khusus dalam catatan sejarah anak di Indonesia.

\section{Referensi}

Alisjahbana, S. T. (1992). Sekilas riwayat hidup perjuangan budaya dan pengalaman pribadi selama di Balai Pustaka, dalam Bunga Rampai Kenangan Pada Balai Pustaka. Jakarta: Balai Pustaka.

\footnotetext{
${ }^{14}$ Kata mungkin ditulis dengan harapan akan muncul fakta lain yang bisa saja berseberangan dengan penulis, sehingga akan bermunculan penulis lain yang berminat untuk mengkaji bacaan anak.
} 
Alkatiri, Z. (2014). Pseudo Nationalism of the Commercial Companies on the Commemoration of Indonesian National Holidays through Non-Commercial Advertising in Print Media in the Years of 1980 to 2008. Advances in Historical Studies.

Christantiowati. (1993). Bacaan anak Indonesia tempo doeloe: Kajian pendahuluan periode 1908-1945, (Skripsi). Jurusan Ilmu Perpustakaan, Fakultas Sastra, Universitas Indonesia.

Djojonegoro, W. (1996). Lima puluh tahun perkembangan pendidikan Indonesia. Jakarta: Depdikbud.

Hill, D. T. (2011). Pers di masa Orde Baru. Jakarta: Yayasan Pustaka Obor Indonesia.

Instruksi Presiden Republik Indonesia Nomor 10 Tahun 1973

Jassin, H. B. (1992). Pertumbuhan diri sebagai kritikus serbaneka pengalaman di Balai Pustaka. dalam Bunga Rampai Kenangan Pada Balai Pustaka. Jakarta: Balai Pustaka.

Junaedhie, K. (1995). Majalah Anak-anak: Peluang yang Dilupakan. Rahasia Dapur Majalah di Indonesia. Jakarta: PT Gramedia Pustaka Utama.

Kamus Besar Bahasa Indonesia. (2018). Diakses dari melalui http://kbbi.web.id.

Membaca sambil berpikir. (1980, Agustus 23). Kompas.

Ricklef, M.C. (2008). Sejarah Indonesia Modern 1200-2008. Jakarta: Serambi.

Sang Perintis Kempis. (2015, Agustus 13).

Sardiman dan Yuliantri, R. D. A. (2012). Dinamika pendidikan pada masa Orde Baru. (Laporan Penelitian). Fakultas ilmu Sosial, Universitas Negeri Yogyakarta.

Sartre, Jean-Paul. (2009). Kata-kata (Coeteau, J. Terjemahan). Jakarta: Gramedia Pustaka Utama.

Si Kuncung (1980, Juli).

Si Kuncung Edisi Spesial Ulang Tahun ABRI ke 36. (1981).

Si Kuncung Istimewa No. 6. (1960).

Si Kuncung No. 2. (1979).

Si Kuncung No. 33. (1980).

Soekanto. (1986, Agustus).

Sutidja, T. (1984, Juli 7). Pasang surut bacaan anak-anak: Dari Si Kuncung sampai proyek Inpres. Sinar Harapan.

\section{Daftar Informan}

Seto Mulyadi, 22 Februari 2015.

Eddy Herwanto, 10 Agustus 2015.

Soerasono, 15 Agustus 2015.

Soekanto, 20 Agustus 2015. 